University of South Florida

DIGITAL COMMONS

Digital Commons @ University of

@ UNIVERSITY OF SOUTH FLORIDA

South Florida

Government and International Affairs Faculty

Publications

Government and International Affairs

5-1-1978

\title{
The Peasants as a Revolutionary Class: An Early Latin American \\ View
}

Harry E. Vanden

University of South Florida, vanden@usf.edu

Follow this and additional works at: https://digitalcommons.usf.edu/gia_facpub

Part of the Government Contracts Commons, and the International Relations Commons

\section{Scholar Commons Citation}

Vanden, Harry E., "The Peasants as a Revolutionary Class: An Early Latin American View" (1978). Government and International Affairs Faculty Publications. 93.

https://digitalcommons.usf.edu/gia_facpub/93

This Article is brought to you for free and open access by the Government and International Affairs at Digital Commons@ University of South Florida. It has been accepted for inclusion in Government and International Affairs Faculty Publications by an authorized administrator of Digital Commons @ University of South Florida. For more information, please contact digitalcommons@usf.edu. 
HARRY E. VANDEN

Department of Political Science

University of South Florida

Tampa, Florida 33620

THE PEASANTS AS A REVOLUTIONARY CLASS:

An Early Latin American View

We do not regard Marx's theory as something completed and inviolable; on the contrary, we are convinced that it has only laid the foundation stone of the science which socialists must develop in all directions if they wish to keep pace with life.

V. I. Lenin (Our Program)

The peasant is one of the least understood and most abused actors on the modern political stage. He is maligned for his political passivity and distrust of national political movements. Yet, most of the great twentieth-century revolutions in the Third World have, according to most scholars, been peasant based (Landsberger, 1973: ix; Wolf, 1969). In Latin America the peasant was once pictured as the archetypical parochial who was more suited for siestas under his sombrero than serious political activity. Stereotypes aside, the region has been no exception to the growing tendency of peasants to become involved in major revolutionary processes. Indeed, beginning with the Mexican Revolution, Latin America has experienced an ever increasing number of revolutionary movments which count on the peasants as a key force in their bid for power. The land occupations which

AUTHOR'S NOTE: An earlier version of this article was presented at the Sixth National Meeting of the Latin American Studies Association, Atlanta, March 1976. I wish to acknowledge my special indebtedness to the Mariátegui family, Julio Portocarrero, Antonio Navarro Madrid, and Jorge Basadre for many courtesies extended while in Peru, and to Edgar Nesman, George Ginsburgs, and Harvey Nelson for critical reaction to the manuscript in various stages of completion. Field research for this paper was made possible by a Fulbright-Hays grant for Peru in 1973-1974.

Journal of Interamerican Studies and World Affairs, Vol. 20 No. 2, May 1978

(C) 1978 Sage Publications, Inc. 
occurred in Northern Mexico and El Salvador in 1976 and 1977 readily attest to the continued restiveness among the masses of the Latin American peasantry. Indeed, even in Latin America, it now seems rather trite to suggest the largely untapped potential for revolutionary action which resides among the rural masses.

Marxism - as the most widespread ideology of revolutionhas had a somewhat curious record on incorporating the revolutionary potential of the peasantry (Mitrany, 1951). While enjoying growing popularity in Latin America, it did not, in the opinion of most scholars, produce an original theorist of peasant revolution until Che Guevara's writings began to appear in the early 1960s. Many would, of course, explain this seeming deficiency on the basis of Marx's belief that it was the urban proletariat which, because of its position in capitalist society, would first achieve revolutionary consciousness and thus lead the socialist revolution. Indeed, in the Communist Manifesto, he and Engles suggested that "the proletariat alone is a really revolutionary class" and that the peasantry is conservative and even reactionary (Marx, 1959: 17-18). The unreconstructed interpretation of Marx which was dominant in the Soviet Union under Stalin thus led the Communist International (during the 1930s and 1940s) to advise the Latin American Communist Parties to wait until a more advanced historical stage had engendered a revolutionary proletariat before they fomented revolutionary action (Program of the Communist International, cited in Miroschevsky, 1942: 56).

There has, nonetheless, been increasing interest in the revolutionary potential of the peasantry among Marxist thinkers.

\section{Leninist View}

Lenin, who creatively applied most of Marx's essential thought to the special conditions he encountered in Russia, did not believe that the Russian peasants, who had been heavily influenced by Russian populism, would form the vanguard of the revolution. This position was reserved for Marx's urban prole- 
tariat. He did, however, believe that the historic conditions were such that the Russian peasantry could enter into alliance with the workers and their vanguard party to overthrow the Czarist regime. Indeed, he broke the peasant population down into four groups (rich peasants, middle peasants, poor peasants and agricultural workers), suggesting that the poorer peasants and rural laborers would be most susceptible to propaganda and organization by the Bolshevik Party ("Preliminary Draft Theses on the Agrarian Question," in Lenin, 1971: 592ff.).

Lenin was, however, aware of the importance of special conditions in developing nations in Africa, Asia, and Latin America. In his opening address to the Second Congress of the Communist International (1920) he called for the creation of a revolutionary spirit among the peasantry, and for the formation of peasant soviets in developing areas (Lenin, 1971: 602-606).

Although the document that contains this last aspect of Lenin's thought does not seem to have been widely circulated in Latin America, it seems certain that José Carlos Mariátegui had access to this or similar documents which were circulated by the Third (Communist) International (Vanden, 1975: 78). New directions within the International seem, however, to have focused on the Soviet model, to the exclusion of revolutionary Marxist-Leninist thought which was more adapted to the specific conditions encountered in the Third World. ${ }^{1}$

\section{Mao}

Unlike many orthodox European communists, Third World Marxists have, however, interpreted Marx and Lenin (who was himself a master of adapting theory to concrete reality) in the light of the specific conditions in which they had to develop their thought. Confronted with the increasingly restive peasant masses in rural China and the abysmal failure of the urban workers uprisings, Mao began, in 1927, to evolve a theory of Marxist revolution which was to place the peasants-and not the workers-in the forefront of the socialist struggle (Mao, 1965, 
Vol. 1: 23-59). His belief that the peasants were the most important revolutionary class in agricultural China developed when he and the other party cadres were forced into the countryside and found that the long-suffering Chinese peasant was ready and willing to revolt against the forces that oppressed him (as indeed he had done sporadically throughout Chinese history). By carefully educating the peasant masses with Mao's interpretation of Marxist-Leninist thought, the communists were able to mobilize them and incorporate them into their revolutionary ranks (Vanden, 1977: 4-5). Thus, Mao concluded that

It was the class struggles of peasants, the peasant uprising and peasant wars that constituted the real motive force of historical development in Chinese feudal society [Mao, 1965, Vol. I: 18].

This view of the peasantry did not, however, emerge full blown from the 1927 "Hunan Report." Rather, it evolved over a period of years as the dynamics of revolutionary praxis forced Mao to revise and refine his original constructs. In fact, as late as 1929, Mao (in a report to the Central Committee of the party) sug. gested that:

The laying of the Party's proletarian base and the establishment of Party cells in industrial enterprises in key centers are the greatest organizational tasks of the Party at present [Mao, in Schram, 1969: 259-260].

Nonetheless, the non-Western, rural peasant perspective which Mao eventually acquired allowed him to adapt revolutionary Marxism to a Third World reality situation in which the peasantry, and not the urban proletariat, was the most exploited and most numerous class (Vanden, 1977: 6).

\section{Guevara}

Che Guevara also forged his Marxist revolutionary theory in the process of struggle. He, like Mao in China, developed his 
Marxist thought in light of the concrete historical conditions which were encountered in $\mathrm{Cuba}$, and thus came to emphasize the rural nature of the struggle. The peasants, and not the urban workers, were to staff the ranks of the rural foco. The revolutionary movement was from the peasant-dominated countryside to the cities. The peasantry would provide the revolutionary force necessary to overthrow the existing regime.

Before Guevara Latin American was not, however, generally believed to have produced any important Marxist-Leninist thinkers. Regis Debray further deplored the general unrevolutionary nature of Latin American Marxist-Leninists and the parties they staffed. The picture he painted of bureaucratized party leaders and intellectuals suggests they were more interested in their jobs as party functionaries than original thought or revolutionary action (Debray, 1967). One is thus led to believe that Latin American revolutionaries had, before Guevara and Castro, been incapable of developing a Marxism which was both revolutionary and suited to the peasant-oriented societies which have characterized most of Latin American up to the present.

\section{Mariátegui}

Such a view would, however, leave out the first major MarxistLeninist thinker in Latin American history-José Carlos Mariátegui. Mariátegui (1894-1930) was a Peruvian intellectual who is best known for his book, 7 ensayos en interpretación de la realidad peruana (Lima, 1928) ${ }^{2}$ and his magazine, Amauta (Lima, 1926-1930). He was also a Marxist pensador of considerable acumen.

Although the 7 Ensayos and some of Mariátegui's literary work have been widely disseminated throughout Latin America and indeed much of the Western world, ${ }^{3}$ his political writings have not been widely read. This is due not only to the Eurocentered nature of the intellectual world, but to the loss of a collection of his writings on the political and ideological evolution of Peru which he mentions in the preface to the 7 Ensayos. 
Lamentably, the manuscript of this work was lost when it was sent to Spain for publication. Nor was the 7 Ensayos ever intended to be a work in political theory (Mariátegui, 1969: 15-16). Up to 1969, Mariátegui's ideological theses and labor writings were either unpublished or buried in obscure publications which never reached a wide audience (Martínez de la Torre, 1947). With the publication of Mariátegui's collected works, a collection of his ideological and political writing was, however, brought to light (Mariátegui, 1969). Ideología y política helps to clarify Mariátegui's ideological orientation and, when supplemented by letters and other documents from the Mariátegui family archive, ${ }^{4}$ gives a solid indication of the innovative nature of Mariátegui's political thought and closely related practical political activity (praxis).

The 7 Ensayos does, however, give some indication of Mariátegui's agrarian-rural focus (see chs. 2 and 3) and of the spontaneous way in which his thought and written work often developed (see the preface and epigram). As to this latter point, it should further be noted that Mariátegui was a journalist by profession and despised the pedestrian, overly organized writing which characterized many academics. Thus, one must often look to several sources to ascertain Mariátegui's thought on a particular matter. Because, then, of this creative style, the loss of the above mentioned manuscript, and the secretive nature of much of Mariátegui's organizational work, this approach becomes particularly important if one is to understand Mariátegui's thoughts on the peasant question.

When Mariátegui returned to Peru from Europe, he was strongly influenced by his contact with classical Marxist writings and the revolutionary socialist forces in France and Italy. Beside reading Marx, Engels, and Lenin, he was exposed to many other European sòcialists including H. Barbusse, G. Sorel, B. Croce, and A. Gramsci (Vanden, 1975: 25-83). Responding to such European interpretations of Marxism, he initially viewed the industrial workers as the principal revolutionary force in a socialist revolution in Peru and thus dedicated much of his time 
to preparing a workers' vanguard for its class role (Mariátegui, 1971a: 77ff.). Mariátegui never, however, thought Marxism should be dogmatically applied and even in this early period (1923-1924) was expanding the classical Marxist conception of the workers as the revolutionary class to include large numbers of class-conscious intellectuals. ${ }^{5}$ Indeed, he was evolving a flexible revolutionary praxis which, although similar to currents in Italy, was to later occasion severe criticism from orthodox communist sectors.

As Mariátegui synthesized the fruits of his ongoing study of Peruvian reality and his voluntaristic reading of Marx, Lenin, and Antonio Gramsci (Vanden, 1975), he began to construct an "American" socialism which, although remaining within the parameters of revolutionary Marxist-Leninist thought, would not be a copy or imitation of another system. "We must," he stated, "give life to Indo-American socialism with our own reality, our own language." It should be "creación heroica" (Mariátegui, 1969: 249). His brilliant study of Peruvian reality (the 7 Ensayos) and nondogmatic approach to Marxism thus enabled him to interpret Marxist thought in light of the rural, agrarian conditions which predominated in Peru and indeed most of Latin America at that time. As such, his thought was very similar to that which we find being applied in much of the Third World today.

The great mass of exploited human beings in Peru was not found among the urban proletariat, which was small, unorganized and (in the mid-1920s) lacking in revolutionary consciousness. There were only a few thousand industrial workers in the entire nation and these were concentrated in Lima. There were, however, millions of peasants who were engaged in agriculture. ${ }^{6}$ This group comprised the vast majority of the total population. Most of this rural population was Indian and tended to work on their own and/or the hacendado's land. Although dissimilar to a classical proletariat, the peasants-Indian and mestizo-were an oppressed and exploited class. Classical Marxist theory would not, however, have viewed this group as a revolutionary class. 
Mariátegui, on the other hand, began to view them differently. He was aware of the many peasant uprisings which had occurred throughout Peruvian history, and of the deep-seated feelings of hostility which the campesino, especially when he was Indian, harbored toward the gamonal and other members of the ruling classes. Huizer and Stavenhagen have, along the same lines, observed that:

Over the years and long before land reform had become a political catchword, the peasants of Latin America had resisted and protested (often violently) the process whereby the expanding haciendas robbed them of their lands and turned them into oppressed peons [Landsberger, 1973: 379].

Indeed, many modern observers have strenuously attacked the "myth of the passive peasant" (Whyte, 1976: 247).

By the late 1920s Mariátegui, like Mao, became convinced that the peasants had the potential for revolutionary action in agrarian society. Indeed, he believed that the only way to improve the living conditions for the (peasant) masses was through a complete structural change of Peruvian economic and social conditions, beginning with a change in the land tenure system which would eliminate the feudal conditions which so oppressed the peasants. Such change was, however, to be accomplished not by an urban vanguard, but by the Indian peasants themselves (Mariátegui, 1928: 6). Thus, the mostly Indian peasants emerge as the strong revolutionary class in Peru. ${ }^{7}$

The Indian peasants would, according to Mariátegui, have a strong disposition toward socialism because of their communal heritage from the Incan Empire (which Mariátegui mistakenly believed was a type of primitive communism) and from their experiences in their "communidades." Their conversion to socialism might be a slow process, but once they had adopted the doctrine, they would hold on to it like few other proletarians:

the socialist idea will serve them with a discipline, a tenacity and a force that few other proletarians from other places could surpass them [Mariátegui, 1969: 46]. 
The history of rebellions and peasant uprisings indicated that the Indian peasants were not docile, as many people thought. Recent history had shown that - as in the case of the rebellion led by Major Gutierrez ${ }^{8}$ - the Indian peasants were capable of rising up against the forces which oppressed them (Mariátegui, 1969: 40). Such uprisings had been brutally repressed because they lacked national leadership or any unifying ideology. Socialism, Mariátegui argued, was the doctrine which could give constructive meaning to this struggle (Mariátegui, 1969: 187-188). He further observed that:

The Indians themselves are beginning to show signs of a new consciousness. ... The new generation knows that Peru's progress will be a fiction or at least will not be Peruvian so long as it is not the work of-and thus benefits - the Peruvian masses who are fourfifths Indians and peasants [Mariátegui, 1928: 6].

Thus it was to be the peasants themselves (most of whom were Indian) who would throw off the yoke of the gamonal and thus initiate the revolutionary process which would result in the implantation of Peruvian Socialism. Indeed, Mariátegui's focus on the rural, agrarian nature of Peruvian society (as in the 7 Ensayos) suggested such a conclusion.

The peasant uprisings which broke out throughout Peru in the 1960s suggest not only the correctness of Mariátegui's Marxist theory, but the accuracy of his empirical observation. In a recent work, Handelman (1975: 126) cites a pamphlet put out by the League of Hacendados in the 1920s which notes 33 peasant revolts in a (typical) 13-month period. Likewise, he suggests that there "is ample evidence that mobilizations of highland communities in the early 1960 s were actually the latest of a continual series of peasant revolts against external exploitation" (Handelman, 1975: 126). Indeed, Mariátegui foresaw the organizational potential of Peru's peasants some 35 years before Hugo Blanco and other Marxist organizers aided in the mobilizations in the Valley of La Convención and elsewhere. One must wonder, then, what the exact potential of Peruvian Marxism would have been if 
it had followed Mariátegui's rural focus, rather than subordinating its national praxis to the Soviet model.

As was the case with Mao, the original nature of Mariátegui's Marxism-Leninism in this and other areas caused considerable conflict with the less flexible Moscow-based Communist International and its followers in and outside Peru. Indeed, the Stalin-dominated post-Zinoviev period witnessed increasing criticism of Mariátegui's ideas. The most spectacular instance of this occurred at the first meeting of Latin American Communist Parties held in Buenos Aires in 1929, where the Peruvian's ideas were crudely attacked by the Latin American Bureau Chief (V. Codovilla of Argentina) and by the Latin Secretary of the International, Jules Humbert-Dorz ("Camaradu Luis"; El movimiento revolucionario, and Portocarrero interview, 1974). Subsequent pressure from the International, the arrival of Eudocio Ravines from Europe, and Mariátegui's untimely death in 1930 allowed a more orthodox Moscow-oriented position (which was championed by Ravines) to triumph within Peru.

Mariátegui's thought was further attacked as national populism in the early 1940s by a well-known Soviet historian who specifically cited Mariátegui's focus on the peasantry as evidence of the unscientific nature of his Marxism (Miroschevsky; 1942). Subsequently (and in large part due to the efforts of now Secretary General of the Peruvian Communist Party, Jorge del Prado), Mariátegui emerged as not only the founding hero of the Peruvian Communist Party (see note 13), but a revolutionary Marxist-Leninist who is frequently lauded by Soviet writers (see note 14; Seminov and Shulgovsky, 1960).

Nor did the Apristas view Mariátegui's formulations with great enthusiasm. After an initial period in which Mariátegui worked' with Haya de la Torre in the Universidad Popular González Prada, Haya was exiled from Peru and was eventually to change APRA from a loose alliance which might temporarily accommodate a socialist group into a nationalist, multiclass party. Although the Apristas and Mariátegui and his followers were both very much interested in the rural, mostly Indian, 
peasantry, they were quite far apart on other issues. The Peruvian APRA was to be a multiclass party which was to include the bourgeoisie, while Mariátegui's Socialist Party was to be solely a working class party. First Luís Alberto Sánchez and then Haya de la Torre accused Mariátegui of being a "Europeanizer" because of his ties to international Socialist thought (Martínez de la Torre, 1947, Vol. 2: 271-286). Mariátegui, in turn, dubbed the APRA the Kuo-Min-Tang of Latin America (Mariátegui, 1969: 87-95). The dispute between the Apristas and Peruvian Marxists was never resolved, and continues into the present day.

Mariátegui's thought was, however, very heavily framed in the context of Peruvian reality and thus it did not, as did Maoist thought, follow the classification scheme which Lenin used (rich peasants, middle peasants, poor peasants, and agricultural workers). He was aware of the special conditions which confronted the sharecroppers (yanacón) ${ }^{9}$ and of the differences among peasant groups in Peru's varied regions. The main focus in most of Mariátegui's writing was on the Sierra peasants whom he usually equated with the Indian population. He did not, however, fail to mention the coastal peasant population, which included a substantial percentage of mestizos as well as Indians.

Indeed, he argued that the coastal peasants had demonstrated their combativeness on several occasions. For instance, in the countryside around Huacho (central coast) "advanced tendencies" had been displayed.

Classist theory and spirit have found a favorable environment there. The first manifestations of proletarian ideology quickly found propagandists among the peasants in Huacho. "Their struggles in the epoch of agitation for the 8-hour working day and against the increased prices for basic foodstuffs put the Huacho peasant in the vanguard of our social movement [Mariátegui, 1929a: 7].

Mariátegui realized that it might be difficult to organize the coastal haciendas but felt that past struggles (such as that of Chicama) indicated the peasants' receptiveness to class propa- 
ganda and organization which could penetrate the most secure hacienda through the going and coming of workers and the new possibilities offered by the motor car (Mariátegui, 1973: 7).10

Nor was the Peruvian thinker unaware of the special conditions which the foreign-dominated agribusiness sector in the North was creating. He believed that the conflict between the modern capitalist enterprises and remnants of the traditional agricultural workers were experiencing (because of their exploitation) could be utilized to hasten the arrival of the socialist revolution. He further suggested that his local contacts set up Marxist study groups to focus the local conflicts in Marxist terms (Mariátegui, 1929b).

The industrial proletariat was not to be the only revolutionary class in agrarian Peru, even though its more conscious elements might contribute more heavily to an initial vanguard which would be responsible for some of the early organizational tasks. A socialist revolution was impossible until the peasant masses became aware of their class role and began a unified socialist movement. These two classes, along with the intellectuals, miners, and even artisans were to form the revolutionary force in Peru. The vanguard which was to lead these groups was not simply a workers party but a party based on the organized work and peasant masses (Martínez de la Torre, 1947, Vol. 2: 397-398). Indeed, Mariátegui seems to have been redefining Marx's concept of the proletariat to fit new historical conditions and thus including class conscious peasants as well as urban workers (Mariátegui, 1973: 17). Unlike Lenin's view of the peasantry, it was not to form an alliance with the urban proletariat to overthrow the bourgeois state, but was to be the most powerful revolutionary class in the struggle to establish a socialist regime. This seems completely consistent with Mariátegui's desire to implant socialism directly in Peru (Mariátegui, 1973: 17). In Peru, as in most of what later became known as the Third World, any popular revolutionary movement which was not based principally in the peasantry would have little chance of success in the foreseeable future. But how, then, was Mariátegui to organize this class? 


\section{Organization}

He realized that the peasantry might be slow to respond to classist propaganda. Thus only some peasants would participate in the initial organizational tasks which were to be carried out largely by class conscious urban workers and intellectuals. Mariátegui's voluntaristic conception of Marxism (which was influenced by Lenin, Henri Barbusse, Georges Sorel, and Antonio Gramsci) would not allow him to wait for the economic conditions to force the peasants to act. He planned to use the vanguardist party, newly created in 1928, and General Confederation of Peruvian Workers, organized in 1929, to educate and organize the rural as well as urban masses. Likewise, he planned to utilize his magazine Amauta and working class newspaper Labor to spread his message. The flexibility of his tactical considerations and the fact that he wanted to create a "workerpeasant" party was later criticized as national populism by the above mentioned Soviet writer who further accused Mariátegui of considering the urban proletariat as nothing more than an "appendage" of the peasant masses (Miroschevsky, 1942: 46-47). Although this would seem to overstate Mariátegui's view, it does indicate how this innovative aspect of his thought was viewed in most orthodox Marxist circles for quite a few years after his death in 1930.

As an indicator of how Mariátegui integrated peasant and worker organization, we would note that the "Manifesto" of the General Confederation of Peruvian Workers (which Mariátegui organized) was "directed to the workers and peasants of the nation so that they would respond to their historic class call and proceed to create union organizations in factories, companies, mines, ports, and in the haciendas, valleys, and Indian communities" (Mariatequi, with A. Navarro and J. Portocarrero, 1969: 139). One of the founding organizations was, in fact, the Federación de Yanaconas (see note 9). Mention was made of the numerous peasant organizations which exist throughout the country and how important it was to have an organization which could educate the peasants in their class role and work for their unification. Indeed, he envisioned a peasantry organized 
in peasant leagues, in peasant communities which tend toward the creation of a "National Federation of Peasant Leagues" [Mariátegui with A. Navarro and J. Portocarrero, 1969: 147-148].

Peasant leagues, we would further note, were among the most effective vehicles used by the Chinese communists and Hugo Blanco to organize the peasantry.

To stimulate rural organizing, Mariátegui devoted entire sections of his literary magazine Amauta ("El Gamonalismo") and his working class newspaper Labor ("El Ayllu") to agrarian problems and peasant organizing. He was even planning to found a separate paper ( $E l$ Ayllu) to heighten class consciousness in rural areas (Mariátegui, 1929c), but was prevented from doing so first by a government crackdown and then by his premature death. He felt that the literacy and linguistic barriers could be overcome by more conscious elements who would translate the main themes of the articles and commentary to their fellow peasants. Likewise, the party cells which were forming throughout Peru were to be used for this purpose. As of 1929, Mariátegui had already begun to send "prepared" workers, peasants, and intellectuals to selected locations on the coast and in the Sierra. These organizers were to bolster classist organization in these areas (Portocarrero Interview, 1974). " Another important way of reaching the countryside was to send peasants who had already been exposed to socialist thought back to their villages so that they could disseminate the doctrine. ${ }^{12}$ This program does not seem to have been implemented on a large scale, although Mariátegui seems to have sent back some peasants whom he knew personally. Unlike some later revolutionaries, he realized that a white or mestizo would be viewed as an outsider in many of the Sierra villages and that it was extremely important to send someone from the same area who could speak the indigenous language. ${ }^{13}$ The importance of this type of contact is stressed in Mariátegui's "Thesis" on the "Racial Problem in Latin America," which was presented at the First Meeting of Latin American Communist Parties in 1929 (Mariátegui, 1969: 83). He also foresaw the possibility of transforming the agrarian committees 
which were forming in the North into instruments of class struggle (Mariátegui, 1929b). Nor should one overlook the fact that Mariátegui never relented in his call for total land reform in order to return the land to those who worked it. In so doing he could not but attract wide peasant support of his programs.

\section{Conclusion}

By 1929, Mariátegui had thus grasped the importance of the peasants as a revolutionary class in less developed societies such as Peru. Likewise, he had even begun to organize this group. The concrete historical conditions had forced him to creatively apply Marx's thought and certain aspects of Lenin's doctrine. In the process, he had evolved an Indo-American socialism which anticipated one of the most controversial, yet original, interpretations of Marxist-Leninist doctrine-that of viewing the peasants, as well as the workers, as a class in society which had a great revolutionary potential because of its relation to the means of production. This was accomplished at about the same time that Mao Tse-tung was evolving a similar doctrine in China. Indeed, the strong emphasis placed on the peasants and land reform by Mariátegui may have actually predated some of the formulations by the Chinese communists. At the very least, the Peruvian's ideas were remarkably advanced for the time in which he was working. He, like Mao, was responding to a Third World reality situation which was vastly different from that which Marx originally envisioned as the locus for socialist revolutions. In so doing, he made an interpretation of Marxism which-while maintaining the revolutionary nature of the doctrine-liberated it from its European birthplace, and indeed made it surprisingly relevant to the rural mobilizations which have come to characterize twentieth-century revolutions in the Third World (see Wolf, 1969).

Although Mariátegui emphasized political education and organization building rather than simply armed struggle, his rural focus anticipated that of Guevara and Castro by almost 30 
years. Similarly, his flexible interpretation of Marxist-Leninist thought occurred better than two decades before most Latin American Marxists could divest themselves of the shackles imposed by a Stalinist-oriented international movement. Nor did he underestimate the importance of violent revolution (see Mariátegui's letter in Espinoza, 1932) or the domination of foreign imperialism (Mariátegui, 1969: 87-95).

Mariátegui's premature death at the age of 35 abruptly terminated the development of his political thought just as he was coming to a mature-if unique-understanding of MarxismLeninism. Much of his political thought was never known outside of a small group of Peruvians. Few of his political writings were, until recently, widely circulated. When Hugo Pesce and Julio Portocarrero presented several of his theses to the First Meeting of Latin American Communist Parties held in Buenos Aires in 1929, his ideas were pointedly attacked by representatives of the Communist International (La Correspondencia Sudamericana, 1929). Nor did Mariátegur's formulations meet with a sympathetic audience among most orthodox communists outside of Peru ${ }^{14}$ until the 1960s, when even the formerly critical Russians reexamined their position on Mariátegui (Seminov and Shulgovsky, 1960).

The unavailability of most of Mariátegui's political writings until very recently, has also made the task of evaluating his thought and praxis a difficult one. As aspects of his political thought become better known, he will almost certainly emerge as the first major Latin American Marxist-Leninist thinker and, indeed, one of the first theorists of Marxist peasant revolution. His, then, was a remarkably current interpretation of MarxistLeninist thought in the Latin American-Third World context. As such, it deserves much more attention and a much wider reading. 15

\section{NOTES}

1. See Humbert-Dorz (1968), Gruber (1974), and M. N. Roy, "Subtleties in the AntiImperialist Struggle" in Gruber (1974: 299-307). 
2. First translated into English by Marjory Urquidi as Seven Interpretive Essays on Peruvian Reality (Mariátegui: 1971b).

3. The 7 Ensayos will soon be in its thirtieth edition, and has been translated into five other languages, including Russian (1963).

4. I am particularly indebted to Dr. Javier Mariátegui and Mr. Sandro Mariátegui for bringing many of the more important documents to my attention. Editora "Amauta" (Lima) will publish Mariátegui's letters in the near future.

5. Letter from Jorge Falcón to a group of Peruvian Socialists, dated Madrid, September 15, 1923. (This letter is found in the Mariátegui family archive.)

6. Mariátegui's definition of "peasant" would seem to be very similar to one of those developed by Landsberger in Rural Protest - "all rural cultivators of low economic and political status" (Landsberger, 1973: 17). Since virtually all the peasants in the highland and most of those on the coast were Indian, he often, however, uses peasant and Indian interchangeably.

7. This aspect of Mariátegui's thought is briefly mentioned in Chang-Rodríguez (1957: 164) and Jorrin and Martz (1970: 280). Neither, however, dwell on the point.

8. This was a rebellion in the 1920 s which involved some 70,000 peasants from Southern Peru.

9. In Peru, Yanacón came to mean a type of Indian sharecropper/laborer who would be allowed to farm part of a (usually coastal) hacienda in return for his labor on the owner's land and/or some other form of payment. Their unique status made them especially susceptible to exploitation by the landowner.

10. This pamphlet is mainly composed of an interview with Mariátegui which was published in La Sierra (Lima) in 1929 and has not yet been included in the Obras Completas.

11. Julio Portocarrero was, at this time, the Socialist group's labor organizer.

12. Interestingly, Handelman (1975: $188 \mathrm{ff}$.) finds that traditional village leaders who had been exposed to modern ideas in the city were key figures in mobilizing traditional communal villages in the Sierra.

13. This was, of course, precisely one of the reasons for Hugo Blanco's initial success in the Valley of la Convención (Blanco: 1972), and conversely, for Che Guevara's failure in Bolivia.

14. After Mariátegui's formulations had been discouraged during the Ravinesdominated 1930s, M. Arroyo Posadas and Jorge del Prado began to defend many of his ideas in the early 1940s in Dialéctica (Havana) and elsewhere. By 1960, Mariátegui had become the hero of the Peruvian communist movement. See especially del Prado's excellent work, Mariátegui y su obra (1946).

15. Mariátegui's thought and praxis are now being reexamined by many scholars in Eastern and Western Europe and in Latin America. See B. G. Kononof et al., José Carlos Mariátegui: Glorious Fighter for Triumph of Marxist-Leninist Ideas in Latin America (in Russian; Moscow: Editorial "Science," 1963); Antonio Melis; Adalbert Dessau, and Manfred Kossok, Mariátegui: tres estudios (Lima: Biblioteca Amauta, 1971); and Diego Meseguer Illan, José Carlos Mariátegui y su pensamiento revolucionario (Lima: Instituto de Estudios Peruanos, 1974).

North American works on Latin American thought have accorded Mariátegui a prominent place among Leftist thinkers and have acknowledged the original nature of his Marxism. See W. Rex Crawford, A Century of Latin-American Thought (Cambridge, 1967); Martin Stabb, In Quest of Identity (Chapel Hill, 1967); Miguel Jorrín and John D. 
Martz, Latin American Political Thought and Ideology (Chapel Hill, 1970); and Harold Eugene Davis, Laiin American Thought (Baton Rouge, 1972).

Considering the importance of Mariátegui, his political thought would seem to merit more extensive treatments in English. Lamentably, the only full-length English work, John M. Baines, Revolution in Peru: Mariátegui and the Myth (University, Alabama, 1972) does not make any significant contribution to an understanding of Mariátegui's views on the peasantry, or in most other areas.

See also the forthcoming work by Jesús Chavarría, José Carlos Mariátegui, 18941930: And the Rise of Modern Peru (University of New Mexico) and Harry E. Vanden, "José Carlos Mariátegui: Revolutionary Political Thought and Praxis in a Developing Nation"' (New School, 1975).

\section{REFERENCES}

BLANCO, R. (1972) Land or Death: The Peasant Struggle in Peru. New York: Pathfinder.

CHANG-RODRIGUEZ, E. (1957) La literatura política de González Prada, Mariátegui y Haya de la Torre. México: Colección Studium-18.

La Correspondencia Sudamericana (1929) El movimiento revolucionario Latinoamericano. Buenos Aires: La Correspondencia Sudamericana.

DEBRAY, R. (1967) Revolution in the Revolution. New York: Grove.

ESPINOZA, E. [Samuel Glusberg] (1932) Trincera. Buenos Aires: BABEL.

FALCON, J. (1923) Letter to a group of Peruvian Socialists (September 15).

GRUBER, H. [ed.] (1974) Soviet Russia Masters the Comintern. New York: Anchor Books, Doubleday.

HANDELMAN, H. (1975) Struggle in the Andes. Latin American Monograph Series No. 35. Austin: Univ. of Texas Press.

HUMBERT-DORZ, J. (1968) L'origine de l'Internationele Communiste. Boundry, France: Baconniere.

JORRIN, M. and J. D. MARTZ (1970) Latin American Political Thought and Ideology. Chapel Hill: Univ. of North Carolina Press.

LANDSBERGER, H. A. [ed.] (1973) Rural Protest: Peasant Movements and Social Change. New York: Barnes \& Noble.

LENIN, V. I. (1971) Selected Works (one vol.). New York: International Publishers.

MAO TSE-TUNG (1965) Selected Works (four vols.). Peking: Foreign Language Press.

MARIATEGUI, J. C. (1973) Acerca del carácter de la sociedad peruana. Lima: No Publishers.

___ (1971a) Historia de la crisis mundial. Vol. 8, Obras Completas. Lima: Biblioteca Amauta.

- (1971b) [Translation of 1928 edition, 7 ensayos en interpretación de la realidad peruana] Seven Interpretive Essays on Peruvian Reality. [M. Urquidi tr.] Austin: Univ. of Texas Press.

(1969) Ideología y política. Vol. 13, Obras Completas. Lima: Biblioteca Amauta. (1929a) "El Ayllu." Labor (Lima) 10 (September 7): 7 
___ (1929b) Letter to Nicanor A. de la Fuente (June 20).

-_- (1929c) Letter to M. Arroyo Posadas (June 5).

___ (1928) "Sobre el problema indigena." Labor (Lima) 1 (Novemer 10): 6.

- - [ed.] (1926-1930) Amauta. Lima.

MARTINEZ DE LA TORRE, R. (1947) Apuntes para una interpretación Marxista de la historia social del Peru (four vols.). Lima: Empresa Editora Peruana.

MARX, K. (1959) The Communist Manifesto in Lewis S. Feuer, Marx and Engels, Basic Writings. Garden City: Anchor Books, Doubleday.

MIROSCHEVSKY, V. (1942) El populismo en el Perú. Dialéctica (Havana) I (MayJune): 41-59.

MITRANY, D. (1951) Marx Against the Peasant. Chapel Hill: Univ. of North Carolina Press.

PORTOCARRERO, J. (1974) Interview with Julio Portocarrero (August 25).

PRADO, J. del (1946) Mariátegui y su obra. Lima: Ediciones Nuevo Horizonte.

SCHRAM, S. R. (1969) The Political Thought of Mao Tse-Tung. New York: Praeger.

SEMINOV, S. and A. SCHULGOVSKY (1960) "El papel de José Carlos Mariátegui en la formación del partido comunista del Perú." Hora del Hombre (Lima) l (January): 65-82.

VANDEN, H. E. (1977) "Marx and the peasantry in Latin America: marginalization or mobilization." Presented at 1977 SECOLAS meeting. (mimeo)

___ (1975) Mariátegui: influencias en su formación ideológica. Lima: Biblioteca Amauta.

WHYTE, W. F. (1976) "Rural Peru: peasants and activists," pp. 241-251 in David Chaplin (ed.) Peruvian Nationalism, a Corporatist Revolution. New Brunswick: Transaction Books.

WOLF, E. R. (1969) Peasant Wars of the Twentieth Century. New York: Harper \& Row.

Harry E. Vanden is presently Assistant Professor of Political Science at the University of South Florida. From late 1973 to early 1975 he lived in Peru, first doing research as a Fulbright Scholar, and then working with the Peruvian government. His publications include Mariátegui: influencias en su formación ideológica. An executive council member of the Society for Iberian and Latin American Thought, he is particularly interested in political thought in Latin America and the Third World. 